\title{
Espetáculos da fé: manifestaçóes religiosas no cinema e as políticas do olhar na contemporaneidade
}

\author{
Luisa Chada Arraes' \\ Maria Eduarda Antonino Vieira ${ }^{2}$
}

\begin{abstract}
Resumo: Este artigo busca discutir como se dão as conexôes entre cinema e religião a partir de uma perspectiva decolonial que enxerga as produçóes imagéticas não apenas como veículos descritores de realidades, mas como exercícios criativos de resistência política. Para isso, traremos contribuiçóes sobre como o cinema foi capturado pela religião, ao passo que a mesma também é utilizada pela própria indústria cinematográfica. Nessa direção, apresentaremos as representaçôes imagéticas que são vinculadas aos referenciais rígidos, monolíticos e engessados sobre a "verdadeira fé", bem como as narrativas que escapam aos códigos hegemônicos e furam regimes de visibilidades, anunciando novas representaçóes e novos olhares sobre o que é o religioso.
\end{abstract}

Palavras-Chaves: Cinema; religião; colonialidade; políticas do olhar.

\section{Faith spectacles: religious manifestations in cinema and the politics of the contemporary gaze}

\begin{abstract}
This article aims to discuss the connections between cinema and religion from a postcolonial perspective that consider image productions not only as vehicles for describing realities, but also as creative exercises in political resistance. Therefore, we will bring contributions on how cinema was captured by religion, while religion is also used by the film industry itself. In this direction, we will present the image representations that are linked to rigid, monolithic and plastered references about the "true faith", as well as the narratives that escape the hegemonic codes and threaten visibility regimes, announcing new representations and new perspectives on what religion is.
\end{abstract}

Keywords: Cinema; religion; colonialism; politics of the gaze.

\footnotetext{
1 Mestranda em Psicologia pela Universidade Federal de Pernambuco. E-mail: luisachadaa@gmail.com

2 Doutoranda em Sociologia pela Universidade Federal de Pernambuco; mestra em Ciência Política (2018).
} 


\section{Introduçáo}

As invençóes tecnológicas da modernidade ocidentalizada desempenharam um impacto direto na construçáo do visível, modificando os sentidos e as experiências, e construindo um universal visual congestionado (BORGES apud HOOKS, 2019). Não há dúvidas de que vivemos uma sociedade visual, na qual somos bombardeados por uma enxurrada de imagens, que enquadram nossa forma de olhar, de pensar e de narrar o mundo que nos cerca, inclusive no que diz respeito ao aspecto religioso ${ }^{3}$. Nesse sentido, é possível dizer que o século XXI é atravessado por uma guerra de imagens e signos, por uma sede de representaçáo e visibilidade que anunciam disputas na ordem do imaginário. Do ponto de vista religioso, concepçóes rígidas, essencialistas e dogmáticas vêm ganhando força no imaginário coletivo brasileiro através da mídia, dos movimentos conservadores, da religião institucional, e até do próprio judiciário. Entretanto, os confrontos estão cada vez mais pulsantes, anunciando a insuficiência de versôes universais acerca da experiência religiosa, e construindo um novo imaginário que, ao conectarse com as lutas cotidianas, transforma a religião em libertação, erotismo, resistência etc.

Como importante veículo de construção do imaginário, o cinema faz-se chave fundamental para a manutenção das narrativas únicas, tendo sido utilizado pela Igreja Católica como estratégia de catequese desde os primórdios dessa arte, e atualizando-se, no cenário brasileiro, nas grandes produçóes audiovisuais pentecostais, inseridas no campo do filme religioso (VADICO, 2009). Entretanto, considerando o poder da imagem diante da possibilidade de construir novas formas de olhar, sentir e experimentar a religião, é perceptível a emergência de disputas no cinema autoral e no cinema de contraposição, que apresentam a expansão do sagrado a partir de outras vozes, corpos e encontros. Assim, é possível acessar formas de religiosidade e sujeitos que corporificam a religiosidade recorrentemente apagados e silenciados do cinema mainstream ${ }^{4}$, mobilizando a complexificação do que é a própria religiosidade.

Concomitante com o desenvolvimento do cinema mainstream, o campo do filme religioso não é um campo simples de ser definido, e voltaremos a ele na próxima seção. Porém, acreditamos que um caminho válido para entendê-lo é começar pelo que não é cinema religioso. Dessa forma, de acordo com a literatura referente, o filme religioso não é aquele que apenas tangencia aspectos religiosos, tampouco aquele que apenas cita a religiáo. $\mathrm{O}$ campo do filme religioso é aquele que vem sendo compreendido como intimamente conectado com as instituiçóes e que tem uma intencionalidade de ser um filme religioso, tanto que apresenta-se como produto "puro" para seus espectadores - estes não apenas sujeitos passivos na relação com o filme, mas que dão o tom da narrativa e até reagem caso não esteja de acordo com os preceitos religiosos tradicionais (VADICO, 2009). Exemplos de filmes religiosos clássicos são "Os Dez Mandamentos" (1956) de Cecil B. DeMille, "Rei dos Reis" (1961) de Nicholas Ray, e "O Milagre de Fátima” (1952) de John Brahm.

\footnotetext{
3 Entendemos que o conceito de religião é polissêmico e imerso em um campo de disputas. Aqui não nos cabe reduzir ou atribuir um significado único, mas apresentar as distintas possibilidades de concebê-lo.

4 A expressão mainstream aqui refere-se tanto a um pensamento difundido mais comum, quanto à generalidade de determinada cultura de massa.
} 
Nessa direção, acreditamos que o público que consome apenas este tipo de conteúdo, não é representativo da totalidade dos espectadores religiosos, sendo possível perceber este direcionamento dentro de um grupo pequeno, coeso, e com tendências sectárias. Dito de outra forma, nos parece que este público tem propensão a enxergar o Outro como ameaça, e quando entra em contato com o diferente, tende a se retrair no intuito de se "proteger", reforçando ainda mais a sua ideia de "verdadeira fé". É importante não perder de vista que a maioria dos religiosos (dentro ou fora das igrejas), entretanto, consomem produtos culturais diversos e transitam por todas as mídias e filmes, sendo reducionista pensar nestes sujeitos espectadores como inerentemente passivos diante daquilo que vem a ser exposto. Reconhecer a heterogeneidade que compóe esse público é, ao mesmo tempo que conectar-se com a ideia de olhar opositor de bell hooks (2019), anunciar a pluralidade de manifestaçóes do religioso que não mais seguem apenas o enquadramento institucional.

Em direção contrária à ideia de como vem sendo definido o campo do filme religioso, o cinema autoral e de contraposição podem produzir peças que dialogam com o Sagrado, entretanto, não aderindo às regras do Campo do Filme Religioso. Diferentemente deste último, que tem como uma das finalidades apresentar uma versão "correta" e "verdadeira" sobre o Sagrado, os filmes de contraposição propóem a expansão da pluralidade de narrativas, ao mesmo tempo que reconhecem a diversidade religiosa que sempre existiu, anunciando o campo de disputas existentes no espaço público através de recursos imagéticos.

É importante destacar que a produção de filmes religiosos não pode ser desassociada da atuação dos próprios religiosos à frente dos espaços de poder hegemônico, desde a própria instituição religiosa, organizaçóes religiosas da sociedade civil, grandes produtoras de audiovisual e estúdios cinematográficos. Nesse sentido, percebemos que a história dos filmes religiosos se confunde com a própria história do Cinema, muitas vezes nela intervindo, quer seja pela estética, pela proposição narrativa, pelo elemento político ou até de censura evidentes (VADICO, 2009). As conexôes entre religião e arte são complexas, sendo possível dizer que a religião anuncia a arte e a arte anuncia a religião.

É preciso ir a fundo no entendimento de como a arte no campo do filme religioso tem relação de dependência com o senso comum, não apenas reproduzindo conhecimentos existentes, mas explorando, distorcendo e nutrindo-os com novas versôes (SILVERSTONE, 1999). Os meios de comunicação utilizam do senso comum quando vinculam, por exemplo, a mulher católica a uma figura náo sexualizada, submissa e dona do lar. Nesse sentido, uma potente contribuição para pensar estas formas de representação é o pensamento de bell hooks (2019), que denuncia uma iconografia colonial na cultura ocidental, e nos convida a desobedecer às normas e formas que a consolidaram, fabricando não apenas um novo olhar, mas também imagens alternativas e críticas ao que já foi produzido no seio das políticas de representação e de visibilidade religiosa. O que a autora compreende como olhar opositor seria, então, o desenvolvimento de um olhar politizado e consciente que abandona a condição de objeto passivo e torna-se sujeito de imaginação ativa, não apenas olhando de forma crítica, mas 
produzindo outras imagens, outros imaginários políticos que possam romper com a supremacia colonial cristã que dominou o Ocidente (HOOKS, 2019, p. 217).

Nesse sentido, ainda que o cinema autoral e de contraposição não sejam produçóes tão monetizadas e, portanto, sem grande alcance, como as produçóes do campo do filme religioso, buscamos argumentar que são justamente as narrativas que escapam aos códigos hegemônicos e furam regimes de visibilidades, que apresentam novas representaçóes e anunciam novos olhares sobre o que é o religioso. Ainda que exista uma defesa do confinamento do aspecto religioso, pautada pela associação direta ao conservadorismo, ao retrocesso, ao atraso, é inegável a presença da religião na política, na mídia e no espaço público. Dessa forma, torna-se importante visibilizar experiências outras que anunciam resistência, sobrevivência e possibilidade de futuro, a partir de corpos de fé que desafiam os signos e símbolos atrelados ao "sujeito religioso tradicional". Assim, defendemos que o próprio ato de olhar de forma crítica para produçóes cinematográficas engessadas acerca da experiência religiosa é por si só uma atitude subversiva, pois mesmo diante de imagens opressoras que apagam a pluralidade do sagrado, é possível fazer emergir narrativas e imaginários outros que denunciam o que antes era invisível. Dessa forma, nos convida bell hooks:

As discussões em torno das novas ordens de representaçáo e de novos regimes de visibilidade habitam o coração da política global contemporânea, que tem como um dos seus principais fundamentos a indissociabilidade entre política e representação. Nessa chave, é preciso defender uma ação transformadora capaz de encontrar maneiras de (re)inventar um mundo possível, numa perspectiva estética, ética e política (HOOKS, 2019, p. 11, grifo nosso).

Entendemos que mesmo dentro do campo das ciências humanas e dos estudos da religiáo, ainda que cercadas de palavras, precisamos, enquanto mulheres do Sul Global, reaprender a ver, pois o olhar tem sido e permanece um lugar de resistência, sendo vital para a nossa sobrevivência convocar novos sentidos a partir do elemento imagético. Acreditamos que as representaçóes cinematográficas contribuem, dessa forma, tanto para a permanência do engessamento acerca do imaginário religioso colonial cristão, quanto também podem ser potência disruptiva de criação e difusão de uma fé expandida.

Antes de seguirmos, ressaltamos a importância de falar sobre "o lugar da nossa escrita" e, assim, revelar alguns aspectos que nos sensibilizam a percorrer este caminho. Tratando-se de um escrito mobilizado por duas mulheres brancas, jovens e de classe média, localizamos nossa pesquisa em um lugar movido por privilégios, ao passo que reconhecemos o encontro que se deu na periferia do conhecimento, no Nordeste do Brasil. Nascidas e criadas na capital de Pernambuco, que desde a década de 1920 foi marcada pela exuberância dos cinemas de rua (REZENDE, 1992), sentimos que esta atmosfera faz parte das memórias coletivas que constroem não apenas o imaginário da cidade, mas nossa própria relação afetiva com o universo cinematográfico.

É importante salientar que a maioria desses cinemas não mais existem, visto que, desde a década de 1980, vários cinemas de rua em todo o Brasil foram fechados. No caso de Recife, 
por exemplo, o antigo Cine Eldorado, que exibiu em 1978 a «Paixão de Cristo», passou a ser uma Igreja Universal do Reino de Deus, e segue até hoje acomodando seus fiéis nos antigos bancos de couro marrom do cinema, ainda causando confusão para alguns desatentos que viveram a Cinelândia recifense e que, por ouvir vozes, músicas e palmas ecoando lá de dentro, podem imaginar que se trata da exibição de um filme.

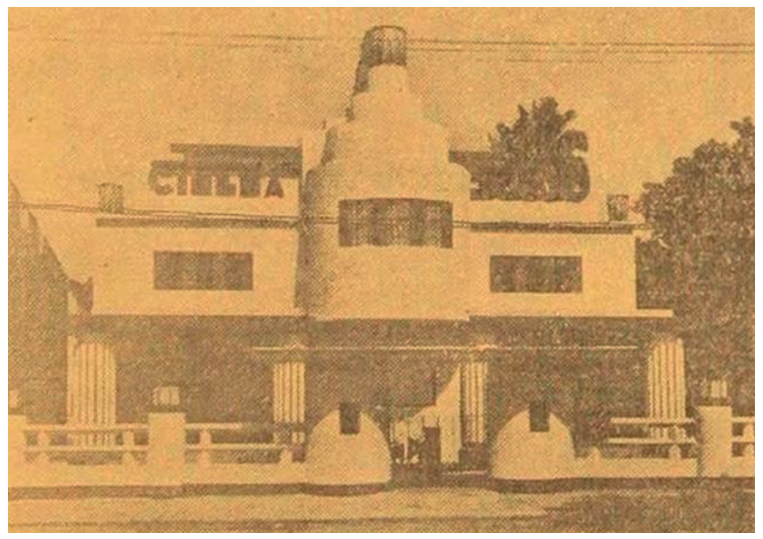

Figura 1: O Cine Eldorado, projeto do engenheiro Jorge Martins, foi inaugurado em 1937, com capacidade para 790 pessoas, e ficava localizado no Largo da Paz, no bairro de Afogados, Zona Oeste da cidade. O bairro era considerado como a "Cinelândia do Recife", por reunir cinco cinemas (Central, Eldorado, Éclair, Pathé e São Jorge). A inauguração aconteceu com a exibição do filme "Noite Triunfal” (1936), de Alexander Hall.

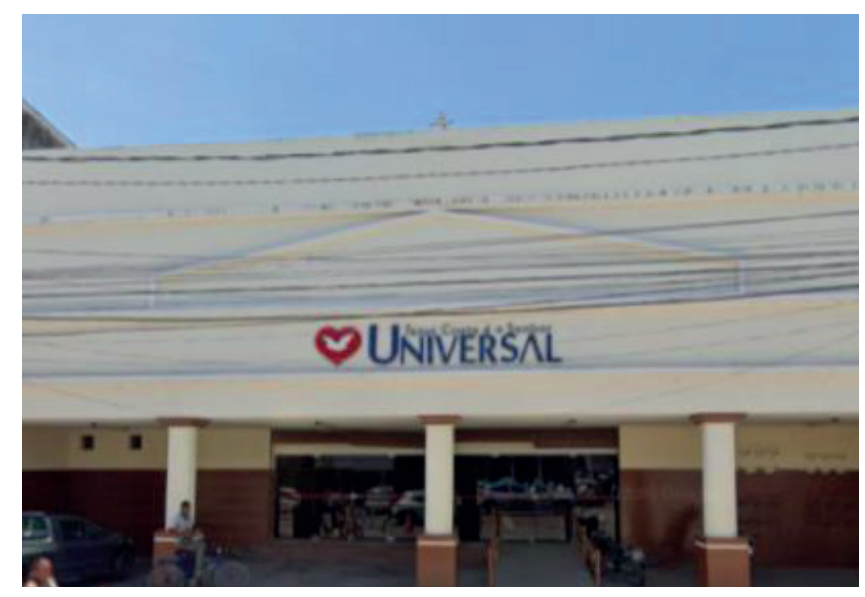

Figura 2: Esta Igreja Universal do Reino de Deus, chamada Universal Afogados, é considerada a sede regional. Nela, as sessões de culto podem ser presenciadas de domingo a domingo, havendo cerca de cinco horários distintos por dia, assim como antigamente eram disponibilizadas as sessões de filmes no Cine Eldorado. Buscamos informações adicionais a respeito da data da renovação da fachada, arquiteto responsável e ano de abertura da igreja, todavia não obtivemos resposta da organização da sede. 


\section{Cinema anunciando religiáo e religiáo anunciando cinema: apropriaçóes e tensionamentos}

Entendendo que as ferramentas coloniais de controle e regulação dos povos se reatualizam no tempo, ganhando novas formas e artifícios, percebemos neste escrito certas produçóes cinematográficas enquanto articuladoras e, ao mesmo tempo, produtos da colonialidade do poder, do saber e do ser. Nesse sentido, o que chamamos de colonialidade vem tocar não só no tangente à permanência de certas estruturas de poder, mas à tomada quase que imperceptível do eurocristianismo enquanto forma de produção e controle de subjetividades. Da mesma forma, um dos elementos cruciais para a permanência da colonialidade, como nos aponta a feminista argentina María Lugones (2014), é o raciocínio baseado na dicotomia central da modernidade colonial: humano e não humano (LUGONES, 2014). Seguindo esta lógica categorial, dicotômica e hierárquica anunciada em binarismos estáticos, temos como exemplo o masculino versus feminino; cultura versus natureza; sujeito versus objeto; e por que não religioso versus profano?

Nesse sentido, do ponto de vista das representaçôes religiosas, apenas as imagens inseridas no enquadramento eurocristão colonizador são tidas como imagens religiosas "verdadeiras", enquanto que o que escapa ou se contrapóe a estes códigos, é continuamente invisibilizado e marginalizado. Ao reduzir, portanto, a própria experiência religiosa a representaçóes imagéticas únicas, cria-se um regime de visibilidade que impossibilita tanto a construção de um olhar opositor e contestatório como a produção de imagens outras que disputam sentidos e formas acerca do religioso. Nosso intuito com estas provocaçóes é o de borrar as fronteiras que afastam o religioso do profano, do erotismo, e da libertação, provocando formas de atuar, de ser e de conhecer que se retroalimentam, criando laços e novos sentidos para esferas que a Modernidade ajudou a separar (MALDONADO-TORRES, 2017).

Assim como a religião, o cinema é constituído de símbolos, mitos, ritos e interditos (MOREIRA, 2008), elementos que ajudam a aproximar o fenômeno da religiosidade desinstitucionalizada do próprio cinema. Dessa forma, é possível visualizar o cinema como religião a partir da sobreposição entre a experiência de se assistir a um filme e sua semelhança com rituais religiosos. Assim, a ideia de um cinema-templo engloba determinadas práticas e simbologias que permitem a conexão com o "mistério" ou "mito" que o altar da tela vai revelar, confundindo as próprias ideias de cinema e de religião (MOREIRA, 2008). Esta "confusão" se insere em um contexto que percebe, tanto no cinema quanto em um ritual religioso, atitudes de adoração, como: o comprometimento com o horário; a disputa pelos melhores lugares; o silêncio e a concentração absoluta; o compromisso com a permanência no ambiente etc. (ADAM, 2010, p. 108).

Diferentemente do que o pensamento moderno sugere ao anunciar o religioso enquanto atrasado, obsoleto e antitecnológico, as instituiçóes cristãs, ao longo da história, desenvolveram formas de articular-se aos inventos midiáticos. Dessa forma, mesmo surgido em uma época de grande crença no racionalismo e cientificismo, o cinema foi recebido não apenas como 
um triunfo da técnica, mas como uma janela para o mágico (MORIN, 1970) que, com o tempo, despertou, nas estruturas religiosas tradicionais, uma possibilidade de manutenção de poder através do cinema de catequese. Assumindo o compromisso de não reduzir o cinema de catequese ao simples proselitismo, entendemos que para além de conquistar fiéis, estas produçóes acabavam estabelecendo conexôes individuais e processos de subjetivação que ultrapassam o próprio objetivo evangelizador.

Nesse sentido, a imbricação profunda entre religiáo e cinema no Campo do Filme Religioso é compreendida por Luiz Vadico (20009) através de algumas características, como: o tema ou assunto religioso deve ser socialmente reconhecido como tal, isto é, destina-se a um público específico e o mesmo deve reconhecê-lo como de seu interesse; busca despertar emoçóes ligadas ao referencial religioso como compaixão, esperança, ao mesmo tempo que deve fortalecer a fé de seus seguidores; é uma produção que possui algum tipo de teologia a ela vinculada, de forma implícita ou explícita (MARSCH; ORTIZ, 1997, p. 22); depende de consultores religiosos para sua produção, veiculação e distribuição; tem a intenção de ser um filme que trate do religioso; tem um "selo" de produto puro e adequado (garantia de qualidade moral dada pelas instituiçôes religiosas através de index, revistas, sugestôes em paróquias e outras indicaçóes encontradas na propaganda dos filmes); e, por último, são produçôes "militantes", que têm o intuito de seguir promovendo as mesmas representaçôes por eles reconhecidas.

Não é novidade que a Igreja Católica, desde as primeiras exibições de filmes, não se mostrou indiferente a essa nova atividade cultural e social (LUDMANN, 1959). A Igreja, no Brasil, em sua forma hierárquica e através de suas organizaçóes, tinha o intuito de orientar seus fiéis frente às mensagens que as obras cinematográficas transmitiam, dando corpo a uma série de estratégias, como, a partir de 1930, a Ação Católica, que buscou participar da Organização Católica Internacional do Cinema (OCIC). O que se buscava através dessa inserção era seguir as diretrizes empreendidas pelo órgão, que era a maior organização representante da relação dos católicos com o cinema. Dessa forma, eram defendidos os seguintes objetivos pela OCIC: 1) colaborar com o desenvolvimento do cinema como expressão artística, instrumento de cultura, de entretenimento e de comunicação entre os homens; 2) ajudar no progresso humano e espiritual dos profissionais do cinema e dos espectadores; 3) favorecer a criaçáa e difusão de películas que podem contribuir com a promoção do homem e o conhecimento da mensagem evangélica. (SOARES, 1988, p. 250; EQUIPE DE REFLEXÃO DO SETOR DE COMUNICAÇÃO DA CNBB, 1994, p. 94).

Considerando os objetivos descritos acima, notamos que, com o intuito de promover a "comunicação entre os homens", o "progresso humano" e o "conhecimento da mensagem evangélica”, as referências imagéticas enquadradas no ideário da Igreja Católica reforçam as noçóes binárias que hierarquizam o mundo moderno. Nesta concepção, percebemos como os "homens" e a "mensagem evangélica" apresentam-se como indicadores do tal "progresso humano". Dito de outra forma, tudo aquilo que escapa a estes indicadores é considerado não humano, e consequentemente bárbaro, herege, pecador. 
É possível perceber uma relação de cumplicidade entre a hierarquia da Igreja Católica e suas organizaçóes na direção de recristianizar a sociedade brasileira a partir do cinema, sendo esse processo também entendido como neocristandade ou neocristianismo. Uma preocupação da Igreja, nesse sentido, era acerca dos "perigos" que ameaçavam o catolicismo no Brasil, entre os quais a emergência do espiritismo, do protestantismo, a maçonaria e o comunismo, se apresentando e disputando novamente o espaço público (SOARES, 1988, p. 216).

Ainda que já fosse visível nesse contexto uma "dispersão" da religião, anunciada tanto pela emergência de práticas religiosas que não só o catolicismo como pelo processo de laicização do Estado como produto da modernidade, a Igreja, agora "sob ameaça", promove, através do cinema, o seu próprio projeto de modernização. Entretanto, vale a pena ressaltar que no Brasil, um país de maioria católica, a Igreja aceitou não apenas sua desvinculação do Estado, como também o desengajamento político propriamente dito, para então assumir um papel público. Isto é, o espaço público da Igreja não é mais o estado ou a sociedade política, mas a sociedade civil (CASANOVA, 1994, p. 62-63).

Buscando batizar não apenas seus seguidores, mas toda a sociedade civil com os seus valores, a Igreja Católica promoveu uma dinâmica que segue acontecendo até os dias de hoje, na qual a partir da dispersão e de uma "falsa" desconexão com as estruturas e hierarquias, penetra de forma profunda seu imaginário moral e valorativo, naturalizando sua presença, que pode tornar-se imperceptível. Vale ressaltar que mesmo que seja possível perceber a influência dos preceitos católicos nas estruturas sociais, hoje visualizamos de forma nítida a presença de políticos assumidamente católicos ou evangélicos, que não apenas buscam garantir a permanência da moral cristã, mas têm o objetivo de ampliá-la. Um exemplo disso é o discurso "Pró-Vida" que, ao posicionar-se em "favor da vida" em qualquer ocasião, sugere um retrocesso em relação às situaçóes em que o aborto já é garantido por lei.

Retomando as reflexôes acerca das interaçôes entre Igreja, Estado e cinema, é importante ressaltar a atuação da Central Católica do Cinema (CCC), que incorporou o trabalho do Serviço de Informação Cinematográfica (SIC), voltado para a "elevação cultural e moral dos espetáculos cinematográficos e teatrais", baseados na encíclica Vigilanti Cura. Em decorrência disso, uma das suas maiores conquistas foi o decreto do ministro da Justiça, que os autorizava a assistir à exibição de filmes para a censura prévia antes de seu lançamento (DEPARTAMENTO NACIONAL DE CINEMA E TEATRO DA AÇÃO CATÓLICA BRASILEIRA, 1948c). A Vigilanti Cura tinha, nesse contexto, a intenção de formar uma nítida consciência cristâ, tanto que em 1958 publicou seu primeiro catálogo geral de filmes com as seguintes classificaçóes: Todos; Adolescentes; Adultos; Adultos, com reservas; Prejudicial; e Condenado, classificando quase 4 mil obras (ALCÂNTARA, 1990, p. 103-104).

Notamos esta influência de forma mais direta a partir do fato de que a encíclica tinha como objetivo orientar e solicitar uma vigilância constante por parte dos fiéis à atividade cinematográfica, estabelecendo seus critérios para a definição do que seria um bom e um mau filme, como podemos notar no seguinte trecho da mesma: 


\section{Os malefícios dos maus filmes}

É geralmente sabido o mal enorme que os maus filmes produzem na alma. Por glorificarem o vício e as paixóes, são ocasióes de pecado, desviam a mocidade do caminho da virtude; revelam a vida debaixo de um falso prisma; ofuscam e enfraquecem o ideal da perfeição; destroem o amor puro, o respeito devido ao casamento, as íntimas relaçóes do convívio doméstico. Podem mesmo criar preconceitos entre indivíduos, mal-entendidos entre as várias classes sociais, entre diversas raças e nações (PIO XI, 1936).

Ao pensar no fortalecimento da tal "consciência cristâ", o uso da ferramenta cinematográfica pode potencializar um imaginário coletivo de representações monolíticas acerca da religião. Assim, percebemos o campo do filme religioso dialogando com o cinema mainstream, através das grandes bilheterias, dos patrocínios, e de roteiros que não exploram a complexidade das temáticas e personagens envolvidos. É interessante ressaltar que muitas destas produçôes do campo religioso se colocam enquanto contra-hegemônicas, argumentando sua nítida oposição diante dos filmes "amorais", "hipersexualizados", e "anticristo" que o cinema mainstream apresenta.

Se, em um primeiro momento, notamos a preocupação da Igreja Católica focada no espectador e naquilo que ele pode consumir, atualmente, não podemos perder de vista que vivemos em uma sociedade hipermidiatizada (SLIMOVICH, 2018, p. 8), na qual não existe a opção para as religiốes não se inserirem nesses espaços. Portanto, a preocupação agora não é apenas com o que é apropriado para o consumo dos espectadores religiosos, mas com a própria produção em si. Ou seja, as religióes passam a ocupar o lugar da mídia transformando o próprio espaço, através de ética e estética própria.

Nessa direção, é importante ressaltar que acreditamos que o Campo do Filme Religioso hoje não está restrito ao enquadramento das Igrejas Católicas ${ }^{5}$. Com o desenvolvimento cada vez mais forte das Igrejas Pentecostais e Neopentecostais, percebe-se uma multiplicidade de denominaçóes que disputam sentidos, representaçóes e experiências, através da rádio, TV, internet e outras mídias. Podemos entrar em contato com esse tipo de produção através de festivais de cinema, plataformas de streaming, canais de YouTube etc. Segue tabela com alguns exemplos:

\footnotetext{
5 Ao nos referirmos à Igreja Católica, entendemos tratar-se de uma instituição histórica, global e, por isso, complexa e multifacetada, exigindo uma dedicada atençấo a cada contexto sobre o qual se fala. Mesmo no contexto brasileiro, é preciso atenção para a heterogeneidade de expressốes do catolicismo.
} 
Tabela 1: Veículos de produção e difusão de filmes e conteúdos religiosos.

\begin{tabular}{|l|l|l|}
\hline \multicolumn{1}{|c|}{ TÍTULO } & \multicolumn{1}{|c|}{ DESCRIÇÃO } & \multicolumn{1}{c|}{ ALCANCE } \\
\hline Cine Gospel & Programação da rede TV Gospel. & Estado de São Paulo \\
\hline Cinema com Cristo & $\begin{array}{l}\text { Projeto que atua no sertão nordestino divulgando o evangelho } \\
\text { através da organização de exibições cinematográficas. }\end{array}$ & Região Nordeste \\
\hline $\begin{array}{l}\text { Mostra de Cinema } \\
\text { Cristão }\end{array}$ & $\begin{array}{l}\text { Mostra nacional competitiva de curtametragens com premia- } \\
\text { ção, que tem como objetivo projetar o audiovisual cristão. }\end{array}$ & Nacional \\
\hline $\begin{array}{l}\text { Festival Internacional } \\
\text { de Cinema Cristão } \\
\text { FICC }\end{array}$ & $\begin{array}{l}\text { Evento cultural que premia os melhores filmes nacionais e } \\
\text { estrangeiros, sendo conhecido como o "Oscar do cinema } \\
\text { cristão". }\end{array}$ & Internacional \\
\hline Univer Vídeo & $\begin{array}{l}\text { Plataforma vinculada à TV Universal e ao pastor Edir Ma- } \\
\text { cedo, que tem disponíveis filmes cristãos, séries e palestras. }\end{array}$ & Nacional \\
\hline Gospel Play & $\begin{array}{l}\text { Plataforma vinculada à TV Assembleia e ao pastor Silas } \\
\text { Malafaia. Disponibiliza filmes, séries, desenhos infantis, } \\
\text { pregações dos principais pregadores do Brasil e do mundo, } \\
\text { documentários, estudos bíblicos. }\end{array}$ & Nacional \\
\hline
\end{tabular}

Fonte: Elaboração própria, 2021.

Dessa maneira, fica visível que existe uma tentativa consciente não só de evangelização e de catequese estabelecida pela ocupação religiosa pelo e no cinema; ao mesmo tempo que no enquadramento católico existe também uma tentativa de recuperar/reagir a perda dos fiéis para os evangélicos e assim restaurar uma hegemonia eurocristá. Entendemos, portanto, que o exercício de estar na mídia, seja no cinema, nas redes sociais, na televisão ou em plataformas de streaming significa disputar voz e participar da vida social. Entretanto, faz-se importante destacar que não é apenas a religião que se utiliza da mídia (Netflix gospel, filmes próprios, televisão e rádio) pela falta de produtos direcionados para o público-alvo, mas a própria indústria percebe esse mercado em ascensão e produz mercadorias nesta direção. Nesse sentido, abordagens que envolvem as relaçôes entre religião e mídia/cinema não podem ser compreendidas de forma unilateral ou estanque, subordinando uma dimensão à outra.

Ao contrário dos prognósticos da modernidade que não apenas anunciaram seu fim, mas a definiram em uma só versão, a experiência religiosa está por toda parte, no cinema e nas mídias, envolvendo dimensóes simbólicas e corpóreas que ultrapassam as dimensões espaciais. Mesmo fora do ambiente de fé tradicional (igrejas, templos, monastérios), é possível seguir produzindo sentidos acerca do religioso, que agora se expandem e se disseminam, marcados por uma interação e exposição muito mais intensa. Dessa forma, é importante defender que a religião nunca deixou de existir, e por isso mesmo não está "de volta" (ORTIZ, 2001, p. 62). Se a modernidade tentou privatizá-la e excluí-la do espaço público (político), compartimentalizando onde a fé cabe e onde não, a experiência religiosa ampliada não parece se enquadrar nestes binarismos hierárquicos (público versus privado; secular versus religioso; moderno versus atrasado; civilizado versus bárbaro etc.).

Não podemos continuar caindo nos equívocos de pensar a religião de forma homogênea, associando-a a um lugar específico e a um sujeito específico, sendo inevitável perceber sua 
presença no cinema, nos cafés, nos restaurantes, em boates, editoras, produtoras de vídeo, agências de turismo; e por isso não sendo possível delimitar onde ela começa e onde termina. Assim, percebemos que quanto mais a religião busca transformar o mundo na direção religiosa, mais ela é atravessada pelos fenômenos da contemporaneidade.

\section{Rupturas e insurgências religiosas: um convite ao exercício do olhar opositor}

Recuperando a ideia de cinema de contraposição já mencionada nas seções anteriores, vemos na noção de um contracinema uma desprogramação das ficçôes mainstream para criar narrativas imagéticas inexistentes até então. Dessa forma, pensando no enquadramento religioso, é importante ter em mente que a cinematografia contemporânea tanto pode ser vista como um laboratório de produçóes de subjetividades hegemônicas, como um "contralaboratório" de produção de realidade. Considerando a capacidade que as subversôes da arte, do ativismo e da filosofia podem trazer às instituiçôes e às subjetividades (PRECIADO, 2008), percebemos o contracinema em expansão contínua pelas esferas mais microscópicas dos nossos corpos, de uma forma tão pulsante que não é preciso "resistir" às imagens (HOOKS, 2019, p. 36). Dito de outra forma, ainda que não se abandone um olhar crítico ou opositor, nestas experiências não se faz necessário defender-se das imagens atreladas à "verdadeira religião".

Aqui entendemos, portanto, o campo do filme religioso não apenas como veículo de catequese, mas também passível de ser apropriado por um olhar crítico que se contrapóe e reivindica imagens e narrativas que conectam a religião às dissidências sexuais, aos feminismos, aos movimentos progressistas etc. Esta forma crítica e posicionada de olhar é capaz não só de "resistir" às imagens, mas de proporcionar, no encontro entre obra e indivíduo, a criação de outros sentidos, imagens e experiências que ultrapassam as representaçóes essencialistas da religião. É um cinema religioso plural em que visualizamos o intercâmbio, a migração, e o sincretismo, e que transgride as marcas da institucionalidade, do dogmatismo e da moral, acessando a materialidade da fé que se cerca de objetos, de coisas, de falas e de ritos pessoais.

A produção religiosa plural tem seus pés fincados em espaços marginais e reafirma o compromisso do cinema como um instrumento capaz de afirmar modos diferentes de vida, de religiosidade, que repensa espaços tradicionais de fé, além de inventar realidades e mundos comuns nos quais as alteridades se encontram e se encenam. É uma criação que corrobora com a ideia difundida nos últimos anos de uma maior sensibilização em relação à pluralidade religiosa no país e que nos convida a ampliar o olhar sobre a experiência religiosa.

Ainda que assumamos a tendência de trabalhar com categorias analíticas na produção de conhecimento científico, é importante destacar, nesse sentido, que o exercício de categorização produz hierarquias e binarismos estáticos, inclusive no cinema. $\mathrm{O}$ ato de nomear um filme como "religioso", por exemplo, instaura e reforça uma narrativa única, marginalizando outras produçóes que apresentam versôes distintas acerca da religiosidade. Dessa forma, pensar nesta diversidade de narrativas, é anunciar uma disputa não apenas relativa ao campo do cinema, mas 
que se insere dentro da própria religiáo. Compreendendo a nomeação como um ato político que envolve tanto inclusão, quanto exclusão, no campo das lutas sociais, também visualizamos a resistência das instituições hegemônicas em permitir que movimentos progressistas se autointitulem católicos ${ }^{6}$, por exemplo.

Brigar por espaço dentro do próprio campo do filme religioso, portanto, visa desestabilizar a própria definição do que seria um "filme religioso" em si. Nesse sentido, a definição de algo como religioso e qualquer tentativa de distinguir um "autêntico" filme da religião e um "falso", perpassa pelos regimes de visibilidade (o que pode ser visto versus o que é apagado), o direito à liberdade religiosa (religióes verdadeiras versus culto, seita, "macumba") e a possibilidade de deslocar o religioso do institucional (religião institucional versus religião vivida). Para os indivíduos, da mesma forma que para os movimentos sociais e para as instituiçóes, as definiçóes da religião não são neutras, mas demonstram o poder de quem define sobre quem é definido.

Lembrando do convite que nos faz bell hooks (2019), é importante questionar quais tipos de imagens subverter, bem como apresentar alternativas críticas e transformar nossas visóes de mundo, nos afastando do pensamento dualista moderno que organiza náo só a religião, mas a sociedade como um todo. Dessa forma, é urgente para se criar um contexto de transformação, abrir espaço para imagens transgressoras e para a visão rebelde fora da lei. Se não houver progresso, "é porque transformamos as imagens sem alterar os paradigmas, sem mudar perspectivas e modos de ver e olhar" (HOOKS, 2019, p.37).

Dentro do fenômeno religioso e das próprias produçôes cinematográficas que anunciam a religião, é possível perceber a tensão constante entre, por um lado, a paralisia da colonialidade do ser, e, por outro, a atividade criativa de ser-sendo (LUGONES, 2014). Para María Lugones (2014), o movimento de ser-sendo só pode ser apreendido a partir de uma perspectiva de subalternidade, que anuncia o pensamento de fronteira como uma consequência da diferença colonial.

Do ponto de vista dos cristianismos, para compreender a emergência de novos interesses no campo de disputa religiosa contemporâneo, é imprescindível considerar a realidade plural existente nos distintos cenários e contextos brasileiros. As intencionalidades específicas, portanto, de cada grupo de atores sociais é capaz de demarcar um território particular e legítimo de construção de fé e (re)compreensão do sagrado, e é assim que surgem as teologias feminista, negra, lésbica, indígena, queer, entre outras. Esta "emergência" não se apresenta da mesma forma para religióes indígenas ou de matriz africana, sendo estas marginalizadas pela modernidade desde o colonialismo até a atualidade, e entendidas como "não religiâo", ou religião bárbara/não humana.

Dessa forma, faz-se importante situar a nossa discussão no território de onde emerge. Uma discrepância nos sentidos atribuídos à religião e aos postulados que previam seu fim,

\footnotetext{
6 Como exemplo, decisão recente do TJ-SP que proibiu a organização nâo governamental Católicas pelo Direito de Decidir de usar a palavra "católicas" no nome.
} 
especialmente no que diz respeito às religióes cristás, se apresenta em cenários europeus, por um lado, e latino- americanos, por outro. Se, naqueles, é possível visualizar com nitidez as disputas entre ciência e religião, ou religião e modernidade, no contexto colonizado é possível afirmar que o cristianismo não necessariamente se contrapóe à modernidade, mas vem encontrando cada vez mais novas e engenhosas formas de articulação. Tendo em vista que a Igreja Católica foi instrumento fundamental para a consolidação dos processos de colonização, no cenário moderno/colonial, é possível perceber o afinamento da própria Igreja com alguns dos ideais de modernidade, dispondo-se, inclusive, a aliar-se a tecnologias como o cinema, o rádio e a televisão, caso necessário, mantendo sua influência e poder "atualizados".

É importante, contudo, considerar que a construção do imaginário religioso brasileiro gira em torno não apenas do exercício da colonialidade do poder e do ser, mas também das respostas da diferença colonial que ocorrem de forma macropolítica (como a resistência das religiôes indígenas e de matriz africana diante do cenário cristão que inscreve uma forma única de ser religioso) e micropolítica (como exercer o olhar opositor diante de imagens violentas, redutoras e particulares exibidas no cinema hegemônico). Como traz Walter Mignolo (2005), o imaginário do mundo moderno/colonial surge da complexa articulação de forças, de vozes escutadas ou apagadas, de imagens compactadas ou fraturadas, de histórias contadas por uma só versão, que sufocaram outras memórias, e de histórias que se contaram e se contam levando-se em conta a duplicidade de consciência que a consciência colonial gera (MIGNOLO, 2005).

Pensamos ser interessante, nesse sentido, articular a prerrogativa da consciência decolonial de Maldonado-Torres (2017) com a ideia de olhar opositor de bell hooks (2019). Nessa direção, a consciência decolonial é necessária para se desenvolver o olhar opositor, caminhando ambos para decolonizaçáo do poder, do saber e do ser, criando um espaço crítico em que a oposição binária que demarca sagrado versus profano; público versus privado; moderno versus atrasado, é perturbada pelos próprios espectadores que, envolvidos em um movimento de resistência próprio, desestruturam o poder que os obrigava a consumir imagens sem criticidade e de forma restrita.

Se no campo do filme religioso, tal como o descreve Luiz Vadico (2010), a narrativa religiosa apresenta características como a linearidade e a universalidade, através de corpos e personagens conectados com os referenciais de humanidade branca eurocristã, o movimento de contracinema possibilita uma experimentaçáo muito mais complexa da religiosidade através de corpos dissidentes, narrativas fronteiriças e da pluralidade religiosa que reivindicam a construçáo de imaginários outros que potencializam a difusão de uma fé expandida. Distanciando-se de representaçóes religiosas tradicionais como políticos da "bancada evangélica", líderes do movimento neoconservador e personagens bíblicos, as produçóes religiosas do contracinema marcam a pluralidade de corpos de fé que reinventam a experiência religiosa.

Assim, é importante que percebamos a contingência e a volatilidade presentes no campo religioso e, portanto, o enxerguemos de forma complexa, considerando a vasta heterogeneidade de quem o constitui. Fica claro que, sendo o cristianismo forte alicerce de estruturas e normas sociais (especialmente em contextos latino-americanos), acessar e dialogar com o conhecimento 
e prática de quem propóe seu deslocamento ou reorganização, viabilizaria um caminho de ressignificação para corpos e subjetividades marginalizadas e desconsideradas pelos discursos cristãos hegemônicos. Ou seja, como pano de fundo, partilhamos do convite lançado por Mary Hunt (2017) como o jogo de forças apresentado em uma disputa constante e insaciável: desestabilizar os fundamentos religiosos hegemônicos torna-se prerrogativa para a mudança mais efetiva dos tecidos sociais.

\section{Referências}

ALCÂNTARA, Maria de Lourdes Beldi de. Cinema, quantos demônios (A relação da Igreja com o cinema). 1990. 210f. v. 1. Dissertação (Mestrado em Antropologia) - Setor de Pós Graduação, Pontifícia Universidade Católica de São Paulo, São Paulo, SP, 1990.

ADAM, Julio Cezar. Religiáo e culto em 3D: o filme Avatar como vivência religiosa e as implicaçóes disso para a Teologia Prática. Estudos Teológicos, v. 50, n. 1, p. 102-115, janjun. 2010.

CASANOVA, José. Public religions in the modern world. Chicago: University of Chicago Press, 1994.

DEPARTAMENTO NACIONAL DE CINEMA E TEATRO DA AÇÃO CATÓLICA BRASILEIRA. Ata da $1^{a}$ Reuniáo Geral do Departamento de Cinema e Teatro da Açáo Católica Brasileira, realizada no dia 25 de junho de 1946. Livro 3, p. 39. Manuscrito. Acervo do Centro Loyola de Fé e Cultura/PUC-Rio.

HOOKS, bell. Olhares negros: raça e representação. Tradução de Stephanie Borges. São Paulo: Elefante, 2019.

HUNT, Mary; BIROLI, Flávia; GEBARA, Ivone; VAGGIONE,Juan. Entre dogmas e direitos: religião e sexualidade. São Paulo: Max Editora, 2017.

IGREJA CATÓLICA, Papa (1922-1939: PIO XI). Carta Encíclica Vigilanti Cura: sobre o cinema. Roma: Livraria Editora Vaticana, 1936.

LUDMANN, René. Cinema, fé e moral. Lisboa: Editora Aster, 1959.

LUGONE, Maria. Rumo a um feminismo descolonial. Estudos feministas, Florianópolis, v. 22, n.3, p.320, set.-dez., 2014.

MARSH, Clive; ORTIZ, Gaye. Explorations in theology and film. Massachusetts: Blakwell Publishers Ltd., 1997.

MALDONADO-TORRES, Nelson. Transdisciplinaridade e decolonialidade. Revista Sociedade e Estado, v. 31, n. 1, p. 75-97, 2017.

MIGNOLO, Walter. A colonialidade de cabo a rabo: o hemisfério ocidental no horizonte conceitual da modernidade. In: LANDER, E. (Org.). A colonialidade do saber: eurocentrismo e ciências sociais. Perspectivas latino-americanas. Buenos Aires, p. 71-103, 2005.

MOREIRA, Alberto da Silva. O deslocamento do religioso no mundo contemporâneo. Estudos de Religiáa, Ano XXII, n. 34, p. 70-83, jan-jun, 2008. 
MORIN, Edgar. O cinema ou o homem imaginário: ensaio de antropologia. Trad. AntônioPedro Vasconcelos. Lisboa: Moraes editores, 1970.

ORTIZ, R. Anotaçôes sobre religião e globalização. Revista Brasileira de Ciências Sociais, Sáo Paulo, v. 16, n. 47, p. 59-74, out, 2001.

PRECIADO, Beatriz. Testo Yonki. Espanha: Espasa, 2006.

REZENDE, Antonio Paulo de Morais. (Des)encantos modernos: histórias da cidade do Recife na década de vinte. 1992. Tese (Doutorado em História Social) - Setor de Pós-Graduação da Universidade de São Paulo, São Paulo, 1992.

SOARES, Ismar de Oliveira. Do Santo Ofício à libertaçáo: o discurso e a prática do Vaticano e da Igreja Católica no Brasil sobre a comunicação social. São Paulo: Paulinas, 1988.

SLIMOVICH, Ana. A midiatização contemporânea do político: os discursos presidenciais nas redes sociais e a reação do cidadão argentino. Revista Eletrônica de Estudos Integrados em Discurso e Argumentaçáo, n. 16, p. 1-25, set. 2018.

SERVIÇO DE INFORMAÇÓES CINEMATOGRÁFICAS. [Texto sobre o SIC e suas atividades]. Rio de Janeiro, 1959. Mimeografado. Acervo do Centro Loyola de Fé e Cultura/ PUC-Rio.

SILVERSTONE, Roger. Why study the media? Thousand Oaks: SAGE, 1999.

SOARES, Ismar de Oliveira. Do Santo Ofício à libertaçáo: o discurso e a prática do Vaticano e da Igreja Católica no Brasil sobre a comunicação social. São Paulo: Paulinas, 1988.

VADICO, Luiz. Filmes de Cristo, oito aproximaçóes. São Paulo: a lápis, 2009. 